\title{
DOSA KEBIJAKAN PANGAN DI INDONESIA: KAJIAN EKONOMI POLITIK DALAM KEBIJAKAN PUBLIK
}

\author{
Wahyu Riawanti \\ Mahasiswa Program Doktor Kebijakan Publik \\ Fakultas Ilmu Sosial dan Politik Universitas Gadjah Mada \\ e-mail : wahyuriawanti@yahoo.com
}

\begin{abstract}
ABSTRAK
This study emphasized in mistakes taken by Indonesian government that explained why food policies have never been in the side of peasents and poor people. The State did not play its role in term of delivering fair food policies for people. It can be seen by the facts that: annual national budget for food and agriculture is relatively small, uneven trade regulation for agriculture products, and unsustainable food policies. It focused in three big sins in food policies which are: trade regulation, political intervention, and institutional conflict of interst. The small design is that imported food related to the givernment good image and political parties'interest. The big design is the everlasting food imports are driven by political party intervention, MNCs interest and international pressure.
\end{abstract}

Keywords: political economy; food policy and agriculture; WTO; political party; food import; peasents

\section{PENDAHULUAN}

Pangan adalah hak warga negara yang dijamin oleh konstitusi melalui undang Undang No. 9 tahun 1996 tentang Pangan. Oleh karena itu ketersediaan pangan yang cukup baik kualitas maupun kuantitasnya harus diupayakan pemerintah karena negara merupakan aktor pertama dan utama yang bertanggungjawab terhadap kesejahteraan rakyatnya. Terkait dengan kesejahteraan pula maka negara berkewajiban untuk meningkatkan kesejahteraan petani dengan tetap memproduksi pangan. Memproduksi pangan dari hasil dalam negeri adalah bagian dari kedaulatan pangan, yang merupakan keharusan bagi suatu negara merdeka.
Data produksi dari tahun ke tahun di Indonesia menunjukkan penurunan kapasitas produksi jika dibandingkan kenaikan jumlah penduduk, kecenderungan jumlah ekspor yang menurun pada kisaran 2005-2010, dan peningkatan jumlah impor pangan terutama sejumlah serealia dan buah-buahan. Sementara itu Nilai Tukar Petani (NTP) yang kecil juga merefleksikan insentif ekonomi relatif rendah dan fluktuatif. Artinya adalah penghasilan produsen pangan lebih kecil dari konsumen secara umum sehingga menyebabkan sektor ini tidak menarik bagi tenaga kerja muda.

Lingkaran setan berawal dari sini. Lesunya perkembangan sektor pertanian menyebabkan rendahnya produktivitas pertanian sehingga penyediaan pangan untuk kebutuhan nasional 
tidak mencukupi. Dengan demikian pemerintah harus menyediakan sebagian pemenuhan pangan melalui impor. Tapi benarkan rendahnya produksi pangan dalam negeri menjadi satu-satunya alasan pemerintah untuk membuka arus impor pangan?

Tulisan ini akan berusaha menjelaskan mengapa kebijakan pangan hampir selalu manis di bibir tetapi berakhir pahit dengan importasi pangan. Kebijakan pangan akan dikaji dari kacamata political economy, yaitu kebijakan di ranah ekonomi tetapi dengan pertimbangan politis sehingga menjadi lebih jelas: untuk kepentingan siapa kebijakan ini diambil, karena jelas bukan untuk kepentingan petani.

Meskipun pangan adalah hak, tetapi mengapa kebijakan pangan dan pertanian lebih sering tidak memihak petani. Pemenuhan pangan sebagai hak dasar sebagaimana diatur dalam UU Nomor 7 tahun 1996 tentang Pangan yaitu “... kondisi terpenuhinya pangan yang cukup bagi rumah tangga yang tercermin dari tersedianya pangan yang cukup, baik jumlah maupun mutunya, aman, merata, dan terjangkau..." masih merupakan salah satu masalah mendasar dari permasalahan kemiskinan di Indonesia (Kartasasmita, 2005: 8).

Kebijakan ketahanan pangan yang lebih banyak bicara tentang beras juga tidak mudah diterapkan. Ketahanan pangan yang melingkupi produksi, akses dan distribusi tidak bisa diselesaikan dari aspek penyediaan pangan semata, atau produksi beras saja. Masalah pangan dan pertanian lebih banyak berakar pada masalah regulasi. Contoh yang paling mudah menjelaskan adalah masalah periode impor beras yang tidak sesuai dengan kebutuhan masyarakat. Bulan Pebruari sampai Mei adalah masa panen bagi petani sehingga pemerintah seharusnya melakukan pelarangan impor pada periode ini. Yang terjadi justru banyak aktivitas impor dilakukan pada awal trimester sampai bulan Maret dengan alasan impor tersebut adalah carry over dari tahun sebelumnya.
Dengan demikian adalah suatu kenisbian untuk mempertanyakan: formulasi kebijakan untuk kepentingan siapa?. Meskipun dalam importasi pangan diketahui bahwa tidak ada satu negara pun yang bisa mengklaim bisa memenuhi $100 \%$ kebutuhan pangannya, kebijakan-kebijakan neoliberal dianggap merusak kedaulatan pangan karena lebih mementingkan perdagangan internasional daripada hak-hak rakyat atas pangan. Kebijakan-kebijakan ini justru meningkatkan ketergantungan pada impor agrikultural dan mengintensifkan peng-korporatisasian pertanian. Dengan demikian kebijakan tersebut membahayakan masyarakat dan pada saat yang sama juga membahayakan budaya, kelestarian genetika alam, dan lingkungan hidup (Darwin, 1999).

Kajian yang paling tepat untuk mengkritisi kebijakan ini adalah aspek ekonomi politik. Ekonomi politik sebagai ilmu yang mempelajari hubungan antara politik dan ekonomi menjelaskan aspek apa yang membawa dunia pertanian ke arah globalisasi pertanian, bagaimana proses ini terjadi dan dan meramalkan trend apa yang akan berlaku pada masa yang akan datang.

Artikel ini bermaksud untuk mempertajam argumen bahwa teori state-centric bisa dijelaskan dalam framework ekonomi politik sehingga dapat menjelaskan tentang kebijakan pangan dan menghasilkan informasi bagaimana pemerintah seharusnya bertindak. Pertama akan dibahas tentang studi literatur terkait dengan studi kasus, pembatasan ekonomi politik dalam pangan dan pembahasan contoh kebijakan impor beras dan impor daging sehingga bisa disampaikan saran bagaimana pendekatan ini dapat dipergunakan untuk kepentingan penelitian maupun praktis.

\section{REVIEW LITERATUR DAN HIPOTESIS}

Kajian tentang politik pangan menarik minat para ahli tidak saja ahli ekonomi pertanian tetapi juga ilmuwan sosial untuk melakukan 
kajian dan penelitian tentang "apa yang kita tanam dan apa yang kita makan". Pangan bersifat global sejak bahan dan pangan berpindah sebagai dampak dari pergerakan manusia menembus batas daerah dan negara. Perdagangan global menciptakan dampak yang tidak sedikit pada kehidupan petani di negara berkembang. Pada satu sisi globalisasi justru menyebabkan kondisi dimana 105 dari 149 negara miskin dunia ketiga menjadi pengimpor pangan (Timmer, 2000). Hal ini berarti negara-negara tersebut tidak memiliki kemampuan yang memadai untuk memproduksi pangannya sendiri.

Kajian dan penelitian pangan sudah sangat sering dilakukan, mungkin ada jutaan judul barangkali dalam kajian teknis atau sosial ekonomi, tetapi jarang tentang kebijakan dari sisi politik atau ekonomi politik.

Penelitian tentang ekonomi politik di kawasan Asia terutama ASEAN adalah bahwa (1) kebijakan pangan justru sering menimbulkan masalah baru negara terkait dengan masalah proteksi perdagangan dan komoditas pangan lokal (Umetsu, 2003; Tolentino, 2002; Gulati, 2002), (2) negara bertanggung jawab dalam pencapaian ketahanan pangan (Beghin, 2003; Molini, 2006), dan (3) aspek sosial lebih dominan menjadi driving arah kebijakan pangan (Rena, 2006; Okpan, 2009; Maxwell, 2010).

Sedangkan penelitian tentang kebijakan pangan dan ketahanan pangan di Indonesia menghasilkantemuanbahwa(1)ketahanan pangan tingkat rumah tangga bervariasi antar daerah dan relatif rendah di sejumlah propinsi (Sawit, 2010; Bustanil Arifin, 2009; Frank R, 1999). (2) kebijakan pangan salah diimplementasikan sehingga masih terjadi malnutrisi dan desa rawan pangan di NTT, Maluku, dan Jawa Tengan (SPI Sujarwoto, 2001; Septiana, 2004; Sumaryanto, 2009) (3) Ketahanan pangan tergantung pada krisis ekonomi dan kenaikan harga pangan (Ariani, 2003; Handewi P. Saliem, 2006; Sri Hastuti, 2008) dan secara langsung merupakan dampak liberalisasi perdagangan (Saliem 2003; Purwoto, 2003; Soehardono, 2004, T. B. Purwantini, 2004)

Salah satu pertanyaan mendasar dalam konteks ekonomi politik adalah whose interest counts?. Pertanyaan normatif yang harus dijawab dalam kajian ilmu ekonomi politik adalah dengan apa yang harus dilakukan oleh pemerintah (what should be set) (Shvets, 2010).

Analisis ekonomi politik menekankan asumsi bahwa, karena kelangkaan sumber daya, tidak ada kebijakan politik yang bisa memuaskan semua pihak secara optimal sehingga ada pihak yang dirugikan dan diuntungkan oleh pemerintah. Konflik kepentingan klasik dari ekonomi politik adalah antara kebijakan yang menekankan efisiensi (misalnya demi percepatan pertumbuahan ekonomi) dan yang menekankan pemerataan (misalnya demi perubahan tertib sosial ekonomi sehingga penghuni lapisan bawah bisa memperbaiki nasibnya). Proses pemilihan alternatif inilah yang sangat penting untuk diperhatikan sehingga mengharuskan kita untuk mempertimbangkan variabel-variabel nilai (value), kepentingan (interest), dan kekuasaan (Mas'oed, 1989).

\section{METODE PENELITIAN}

Metode yang dipergunakan dalam penelitian ini adalah metode kualitatif dan triangulasi dari studi literatur terdahulu, telusur media, dan wawancara narasumber. Metode ini dipakai karena sesuai dengan fokus penelitian untuk mengkaji kasus yang terbatas sifatnya namun mendalam (in-depth) dan menyeluruh (holistic), dalam arti tidak mengenal pemilihanpemilihan gejala secara konsepsional ke dalam aspek-aspek yang kita kenal sebagai variabel (Soetandyo, 1997). Menurut Straus and Corbin (2003), penelitian kualitatif juga sangat sesuai untuk mengungkapkan sesuatu di balik fenomena yang baru sedikit diketahui atau untuk 
mempelajari dimensi ganda fenomena yang kompleks dan belum banyak diketahui (Polit \& Beck, 2004).

Penelitian ini menggunaka informasi narasumber sebagai data primer di mana narasumber diharapkan bisa memberi penjelasan dan informasi dengan melalui wawancara semi investigasi untuk mengidentifikasi masalah dan diskrepansi di balik kebijakan dan importasi pangan. Metode diharapkan dapat menjabarkan realitas obyek penelitian tentang kebijakan pangan dan impor beras yang kompleks untuk selanjutnya memberikan penafsiran dan pemaknaan dengan mengaitkan hasil analisis dan teori yang sudah ada.

\section{HASIL PENELITIAN DAN PEMBAHASAN}

Dari penelusuran pustaka ditemukan bahwa hal yang paling mendasari kegalan kebijakan pangan adalah tarik ulur kepentingan antar sektor yang saling tidak sesuai. Kebijakan pangan di indonesia merupakan kebijakan yang memiliki banyak ibu di kementerian berbeda. Penyediaan pangan dalam hal beras misalnya, melibatkan koordinasi dari Kemeterian Pertanian untuk input produksi dan lahan tanam, Kementerian PU untuk masalah irigasi, kementerian sosial untuk bantuan, kementeria UMKM untuk masalah pinjaman modal, Kementerian Perdagangan untuk Impor Beras, Kementerian Keuangan untuk kuota impor dan bea masuk, dan Bulog sebagai importir dan pengadaan beras lokal.

Benturan kepentingan paling sering terlihat adalah ketika Kementerian Pertanian mencoba melakukan pendampingan pada petani untuk meningkatkan produksi beras dan di saat yang sama pemerintah harus mengamankan stok pangan nasional. Kementerian Perdagangan tidak bisa menghindari impor beras yang berdampak pada turunnya Nilai Tukar Petani (NTP) karena anjloknya harga beras dalam negeri.
Hasil penelitian tentang NTP dan surge (serbuan) impor ( Sawit dan Lokollo, 2007) menunjukkan bahwa NTP menurun karena adanya bias bahwa petani tidak selalu menjadi net consumer sepanjang tahun. Petani menjadi net consumer hanya pada saat musim paceklik (MP) tetapi surplus beras terjadi pada musim panen raya (MPR) dan musim panen gadu (MPG). Dengan demikian pengaturan impor beras perlu diperkuat yaitu hanya pada saat musim paceklik.

Tabel 1

Jumlah Impor Beras 1998-2010

\begin{tabular}{rrrr}
\hline \multirow{2}{*}{ Tahun } & \multirow{2}{\text{Imporoleh}}{$\begin{array}{c}\text { Jumlah Total Impor (1.000 ton) } \\
\text { Bulog }\end{array}$} & \multicolumn{2}{c}{ Jur } \\
\cline { 3 - 4 }$(\mathbf{1 . 0 0 0}$ ton) & \multicolumn{1}{c}{ Data BPS } & Data TRR \\
\hline 1998 & 5.959 & 6.011 & 6.079 \\
1999 & 1.527 & 4.751 & 4.182 \\
2000 & 531 & 1.355 & 1.511 \\
2001 & 68 & 644 & 1.384 \\
2002 & 1.000 & 1.805 & 3.740 \\
2003 & 655 & 228 & 2.737 \\
2004 & 29 & 237 & 633 \\
2005 & 68 & 190 & 446 \\
2006 & 291 & 437 & 666 \\
2007 & 1.293 & 1.406 & 1.705 \\
2008 & 30 & 290 & 342 \\
2009 & - & 250 & 304 \\
2010 & 1.350 & 44 & 207 \\
\hline
\end{tabular}

Sumber: BPS, TRR dan Bulog, 2010

Pemerintah tidak dapat menghindari impor beras secara besar-besaran dengan untuk alasan mengamankan pasar. Data impor yang didapatkan dari sumber berbeda menunjukkan angka yang tidak sama. Sejumlah fakta yang menarik untuk dicermati adalah : (1) tidak ada impor pada tahun 2008, (2) Pada tahun 2003 dan 2008 jumlah impor yang dilaporkan pada BPS jauh lebih rendah dari yang dilaporkan oleh negara eksportir (The Rice Report), bahkan data BPS pada tahun 2003 lebih kecil dari data Bulog sebagai importir. Pada tahun tersebut isu 
swasembada pangan adalah komoditas politik yang strategis menjelang kampanye Pemilu 2004 dan 2009.

Sementara itu kebijakan pemerintah terkait pembebasan bea masuk atas impor beras dalam Peraturan Menteri Keuangan (PMK) No.241/2010 dinilai sebagai kebijakan yang inkonstitusional (Arifin, 2011), bertentangan dengan rencana kerja pemerintah maupun Undang-Undang tentang APBN 2011 karena bertentangan dengan komitmen swasembada beras. Komitmen swasembada pangan tersebut tertuang dalam Nota Keuangan \& RAPBN 2011 yang kemudian dilegalkan menjadi UU APBN 2011 serta Peraturan Presiden No.29/2010 tentang Rencana Kerja Pemerintah.

\section{Gambar 1.}

\section{Grafik Jumlah Impor Beras 1995-2010}

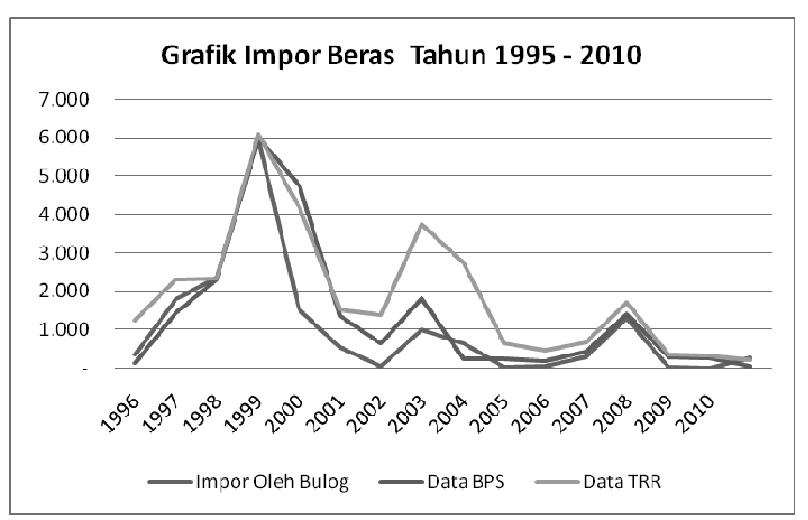

Sumber: BPS, TRR dan Bulog dalam Riawanti (2011)

Masalah masalah tersebut bisa dielaborasi menjadi lebih sederhana menjadi tiga bagian sebagai berikut: pemerintah, birokrat, dan perdagangan dunia. Dominasi kepentingan asing dibahas secara mendalam dalam beberapa laporan hasil penelitian.

Dalam pembahasannya mengenai dana global perekonomian Indonesia, Winters (1996) memperkenalkan istilah "capital controllers" atau pengendali modal yaitu pribadi atau lembaga, bisa bersifat pemilik dana dan tidak mepunyai akses langsung terhadap dana yang telah disertakan seperti dana pensiun; bisa pula bersifat kumpulan investasi yang besar dari berbagai negara yang memiliki birokrasi tersendiri seperti World Bank (WB), Asian Development Bank (ADB), USAID, dan beberapa konsorsium beberapa Negara seperti IGGI yang kemudian menjadi CGI (dibubarkan pada Januari 2007) (Winters 1996).

\section{Gambar 2}

\section{Peta Empiris Kebijakan Impor Beras dalam Kerangka Torisasi}

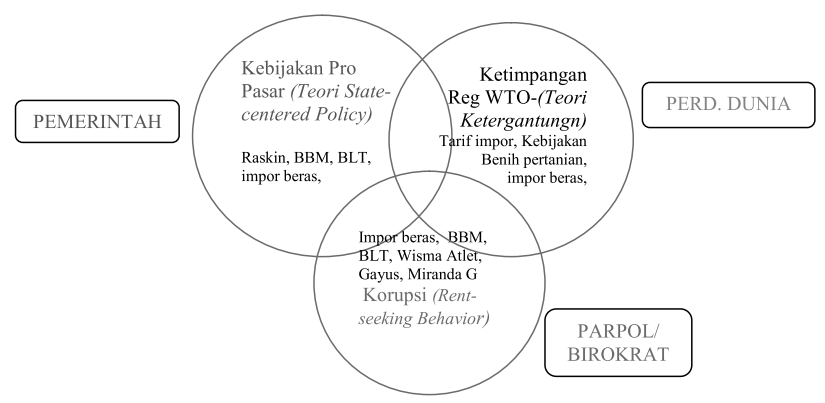

Sumber: Hasil Penelitian Wahyu Riawanti

Salah satu faktor yang menentukan kebijakan impor beras adalah disparitas harga lokal dan internasional. Impor beras dari negara ASEAN terutama Thailand mengalami peningkatan jumlah dalam jumlah yang signifikan. Sejak 1997 impor beras dari Thailand mencapai $30 \%$ dari total impor beras Indonesia.

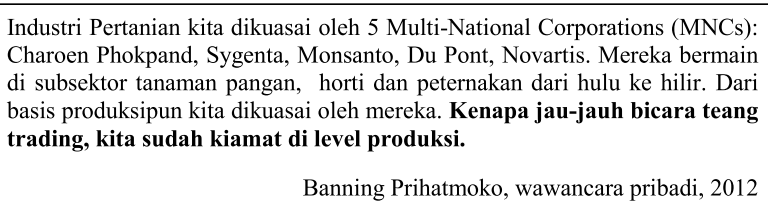

Sementara itu ekspor komoditas pertanian ke negara ASEAN relatif kecil kecuali ke Singapura yang melakukan re-ekspor ke negara lain. Dengan mempertimbang kan kondisi thin market ini, negara manapun akan berada dalam situasi tidak aman ketika menggantungkan kebutuhan pangan pada impor dari negara lain (Timmer, 2000). Ketidaksiapan pemerintah 
sehingga dari tahun ke tahun menjalankan kebijakan pangan dan pertanian yang bias produksi disampaikan seorang pengamat pelaku pertanian dan pengamat kebijakan pangan di atas.

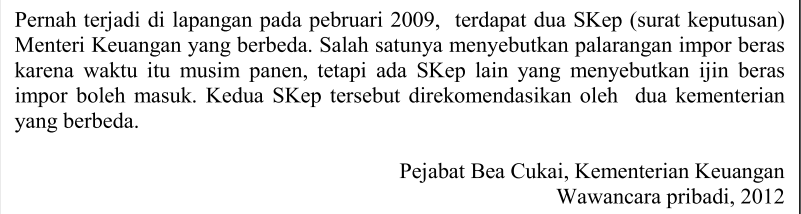

Pejabat Bea Cukai, Kementerian Keuangan Wawancara pribadi, 2012

Melalui penelusuran media juga ditemukan sejumlah besar pelanggaran apa saja yang pernah terjadi dalam implementasi kebijakan pangan terutama importasi pangan. Salah satu faktur adalah lemahnya koordinasi antar kementerian seperti dalam temuan di atas.

Konfirmasi melaui in-depth interview dilakukan untuk mengkonfirmasi bahwa ada peran partai politikl di balik kebijakan importasi pangan (melalui wawancara pribadi dengan bukti rekaman dan transkrip). Dalam hal ini ditemukan sejumlah fakta tentang penyalahgunaan dan manipulasi jumlah ijin impor pangan yang merupakan lahan basah bagi pelaku pemburu rente untuk mendapatkan kemudahan dari pemerintah.

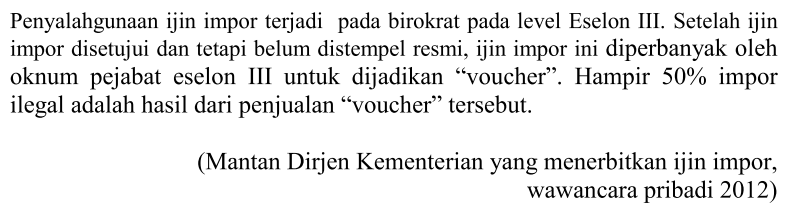

Penyalahgunaan ijin impor terjadi pada birokrat pada level Eselon III. Setelah ijin impor disetujui dan tetapi belum distempel resmi, ijin impor ini diperbanyak oleh oknum pejabat eselon III untuk dijadikan "voucher". Hampir 50\% impor ilegal adalah hasil dari penjualan "voucher" tersebut.

(Mantan Dirjen Kementerian yang menerbitkan ijin impor, wawancara pribadi 2012)

Hasil penelitian pada sub bab sebelumnya menjelaskan situasi kebijakan pangan sampai saat ini menunjukkan setidaknya dua hal yaitu: (1) kenyataan bahwa kita tidak bisa menegasikan globalisasi dengan aktivitas importasi pangan karena Indonesia meratifikasi regulasi perdagangan bebas, dan (2) tidak hadirnya negara dalam mengakomodasi kepentingan rakyat dan justru memfasilitasi kepentingan Partai dan kepentingan Muliti-national Corporations (MNC) dalam tataran produksi pangan melalui budidaya pertanian.

\section{KEBIJAKAN PANGAN: UNTUK KEPENTINGAN SIAPA?}

Kebijakan publik seringkali dijalankan untuk tidak melayani kepentingan publik. Menurut Galbraith dalam Parsons (2008), salah satu karakteristik utama negara modern adalah cara di mana kekuasaan birokratis dan teknokratik semakin bertambah dengan melayani kepentingan "dirinya sendiri" daripada melayani kepentingan publik.

Dalam hal ini kebijakan yang paling mudah yang akan diambil. Dalam sektor industri misalnya, Indonesia mengekspor timah mentah dan mengimpor komponen elektronik berbahan baku timah. Tidak heran bila industri manufaktur tergantung bahan baku impor tinggi, bahkan sepuluh komoditas impor teratas Indonesia saat ini adalah barang setengah jadi dan komponen (Mas'oed, 2003). Dalam hal ini terfjadi transmisi nilai: internasionalisasi kapital oleh perusahaan multinasional sangat tergantung pada proses informasi global yang canggih. Proses informasi global yang semakin canggih tersebut menekankan dua hal penting yaitu liberalisasi ekonomi kapitalis dan sentralisasi dan pengendalian proses pembuatan keputusan global .

Kecenderungan ini juga terjadi pada kebijakan ekspor-impor terkait pangan. Pada dasarnya ketika pangan secara konstitusi dalam UU No. 7 tahun 1996 dinyatakan sebagai hak, maka menyerahkan pada pasar yang berujung pada ketergantungan pangan impor adalah suatu bentuk pelanggaran. Apalagi jika RUU Pangan tahun 2012 disahkan, yang di dalamnya menjamin kedaulatan masyarakat untuk menyediakan sendiri pangannya. Faktanya sebagian besar mekanisme pengadaan pangan di Indonesia diserahkan pada pasar.

Sementara itu dalam teori ekonomi kesejahteraan (welfare economic) menurut Feldman (2000:7), kondisi Pareto optimal harus diciptakan. Setiap buah apel impor yang 
kita konsumsi akan mengurangi kesempatan angkatan kerja pertanian dalam jumlah tertentu (Riawanti, 2012). Itu artinya setiap konsumen mengoknsumsi pangan impor tersebut akan menimbulkan kerugian bagi petani lokal secara tidak langsung.

Dalam teori ekonomi, ketika A melakukan suatu tindakan yang merugikan B tetapi A tidak memberi ganti rugi (mekanisme pasar) terhadap kerugian $\mathrm{B}$, dimana dalam situasi tersebut pasar tidak memberikan sinyal pada A maka situasi yang dihasilkan adalah situasi yang tidak Pareto optimal. Dalam hal ini hubungan antara pasar kompetitif dengan optimalitas dihancurkan.

Solusi yang ditawarkan adalah penambahan pajak terhadap harga barang impor. Pada prionsuipnya ekonomi kesejahteraan memulihkan hubungan antara pasar yang kompetitif dan optimalitas, sehingga pasar kompetitif menjadi sempurna. Sisi praktis dari ekonomi kesejahteraan memulihkan kesenjangan antara pasar privat yangs empurna dengan realitas adanya eksternalitas dan barang publik (Feldman, 2000). Pada akhirnya kembali pada peran negara apakah akan memihak pada rakyat dengan utopia ekonomi kesejahteraan, atau bermain aman di jalur politik yang memberikan jalan hanya pada pendekatan mainstream.

Kepentingan parpol melalui oknum elit politik dan oknum birokrat. Menurut Mas'oed (2003: 137) ada 3 pola pemikiran dalam pembangunan di Indonesia yaitu (a) Politik Sebagai Panglima (PSP), (b) Ekonomi Sebagai Panglima (ESP) dan (c) Moral Sebagai Panglima (MSP). Pendekatan pertama: politik menekankan peran negara, kedua: menekankan peran pengusaha, ketiga people power, yaity mekanismae pembangunan yang lebih mengutamakan kekuatan rakyat.

Misalnya demi menanggulangi krisis pembangunan, memburuknua perusakan lingkungan dan maka pendekatan yang disasarkan pada ideologi populisme ini menganjurkan pengaktifan kembali komunitas lokal. Ketika pemikiran 3 ini dianggap utopian, maka maka para pendukungnya menganggap 2 pemikiran yang lain juga utopian. Bedanya pendekatan yg mainstream mendapat dukungan politik, sedangkan pendekatan alternatif tidak. Dengan demikian pendekatan yang ketiga ini sama sekali tidak dilakukan dalam kebijakan importasi pangan di Indonesia. Impor pangan hanya membantu konsumen jangka pendek tetapi tidak memihak produsen sama sekali.

\section{KESIMPULAN DAN SARAN}

Hunger is a silent killer; the holocaust of our time. Kelaparan adalah peristiwa holocaust yang terjadi pada masa sekarang (Falcon, 2005). Kelaparan akan terjadi ketika ketergantungan terhadap impor pangan tetap berlangsung sementara kondisi pasar di tingkat dunia tidak selalu terjamin. Kebijakan impor pangan berpusat pada pemerintah dan lebih peduli pada politik pencitraan dan laporan statistik "surplus tapi impor" sehingga tidak menghasilkan kesejahteraan bagi rakyat. Sehingga kemudian, yang dibutuhkan adalah ketegasan pemerintah.

Kesimpulan:

1. Karena Indonesia sudah meratifikasi Agreement of Agriculture, maka pemerintah harus mengikuti regulasi WTO yang banyak bisa diharapkan karena dominasi negara maju. Dengan demikian kunci keberhasilan perdagangan pangan ada pada aturan internal.

2. Dalam kebijakan pangan, pelanggaran terjadi bukan pada pembuatan kebijakan (berbeda dengan undang-undang kesehatan misalnya), tapi dalam implementasi kebijakan impor dan pengawasannya.

3. Kementerian teknis yang melibatkan petinggi partai politik menunjukkan benturan kepentingan yang sangat potensial menyebabkan kerugian negara. 
Saran:

1. Ketegasan pemerintah untuk membenahi regulasi perdagangan pertanian. Regulasi WTO tidak bisa banyak diharapkan karena dominasi negara maju, tapi bukan alasan untuk menyerahkan pangan pada mesin pasar. Vietnam dan Malaysia adalah contoh pentingnya ketegasan pemerintah

2. Transformasi total melalui penegakan hukum, dan secara khusus pemisahan kementerian teknis dari pejabat partai politik sehingga tidak ada benturan kepentingan.

\section{DAFTAR PUSTAKA}

Ambardi Kuskridho, 2009. Mengungkap Politik Kartel : Studi tentang Sistem Kepartaian di Indonesia era Reformasi. Jakarta. Kepustakaan Populer Gramedia.

Feldman, Allan M. 2000. Ekonomi Kesejahteraan. Diterjemakhkan oleh R. Maryatmo dan Retnandari. Universitas Atma Jaya Yogyakarta

Hira Jhamtani. 2008. Rawan Pangan Bukan Perbuatan Tuhan. Jurnal Ilmu Sosial Transformatif Wacana. Edisi 23 Tahun 2008. Insist Press.

Khor, Martin. 2010. Memperdagangkan Kedaulatan: Free Trade Agreement dan Nasib Bangsa. Insist Press.

Mas'oed Mohtar. 2003. Ekonomi-Politik Internasional dan Pembangunan. Pustaka Pelajar. Yogyakarta.

Khudori. 2008. Merombak Struktur Pasar Komoditas Pangan. Jurnal Ilmu Sosial Transformatif Wacana. Edisi 23 Tahun 2008. Insist Press.
Krueger Anne, O. 1974. The Political Economy of the Rent Seeking Society. The American Economic Review. Vol. 64No. .

Nyak Ilham. 2010. Analisis sosial ekonomi dan strategi pencapaian swasembada daging 2010. Analisis Kebijakan Pertanian 4 (2): $131-145$.

Parsons, Wayne. 2008 Public Policy: Pengantar Teori dan Praktik Analisis Kebijakan. Cetakan ke-3. Kencana. Jakarta

Riawanti, Wahyu. 2011. Kajian Ekonomi Politik State-centered dan Rent-seeking dalam Kebijakan Impor Beras. Jurnal Kebijakan dan Administrasi Publik UGM Vol 16 Peb 2011.

Riawanti, Wahyu. 2012. Kajian Ekonomi Politik Kebijakan Impor Daging Sapi Menuju Swasembada Daging. Dalam Indonesia Bergerak: Percik Pemikiran Komunitas Sekip untuk Perubahan. Editor Agus Pramusinto dan Erwan Agus Purwanto.

Sen, Amartya. 2000. Development As Freedom. Anchor Books. A Division of Random House. New York

Shvets, Julia. 2010. Distributional Politics and Electoral Incentives: Evidence from Seven US State Legislatures. European Journal of Political Economy, 2010

Tullock, Gordon. 2003. The Origin of rentSeeking Concept. International Journal of Business and Economic. Vol 2 No 1:18

Winters, Alan Neil McCulloch, Andrew McKay (2004). Trade Liberalization and Poverty: The Evidence so Far. Journal of Economic Literature, Vol. 42, No. 1 (Mar., 2004), pp. 72-115. 